\title{
The cost of livestock lost to lions and other wildlife species in the Amboseli ecosystem, Kenya
}

\author{
Margaret W. Muriuki $^{1} \cdot$ Hellen Ipara $^{2} \cdot$ John W. Kiringe ${ }^{3}$
}

Received: 16 September 2016 /Revised: 16 May 2017 / Accepted: 18 May 2017 /Published online: 9 June 2017

(C) The Author(s) 2017. This article is an open access publication

\begin{abstract}
Though retaliatory lion (Panthera leo) killing as a result of livestock predation in the Maasai group ranches between the Tsavo NPs and Amboseli is remarkably high, other wildlife species are known to kill livestock. Surprisingly, lions suffer the most from retaliatory killing by the Maasai community for killing livestock. The extent of livestock predation by lions in comparison to other species is unknown. This study was carried out in the Olgulului group ranch (OGR) located adjacent to Amboseli National Park in June 2009. The cost of livestock killed by each of these species including lion, hyena (Crocuta crocuta), cheetah (Acynonyx jubatus), leopard (Panthera pardus), olive baboon (Papio cynocephalus), black-backed jackal (Canis mesomelas), and African elephant (Loxodonta africana) was analyzed. Questionnaires, focus group discussions, and key informant interviews with officials from OGR, Kenya Wildlife Service (KWS), and compensation scheme organizations were the methods used to collect information. Cluster and systematic sampling techniques were used to select a sample of 199 respondents from OGR. Lions were blamed for $40.5 \%$ (US\$ 374,603) of the value of livestock lost to wildlife. The costs of livestock lost to hyenas and lions were not significantly different $(q=0.24, p=0.968)$.
\end{abstract}

Margaret W. Muriuki

magmuriuki@gmail.com

John W. Kiringe

jwkiringe@gmail.com

1 Tourism and Hospitality Management, Karatina University, P. O. BOX 1957-10101, Karatina, Kenya

2 Wildlife Management, University of Eldoret, P. O. BOX 1125-30100, Eldoret, Kenya

3 Kenyatta University, 293, Nairobi 00100, Kenya
Although hyenas killed more livestock compared to lions, the economic damage between the two was not significantly different because lions attacked cattle which had high economic value. Conservation of lions will be increasingly difficult if the current levels of predation are not reduced to economically and socially acceptable levels.

Keywords Lion $\cdot$ Livestock $\cdot$ Predation $\cdot$ Conservation . Economic

\section{Introduction}

The most severe threats to large carnivores in Africa result from human population growth and the associated conflicts brought by livestock predation by carnivores. After the Europeans colonized most of Africa, large carnivores including lions (Panthera leo) were considered vermin because they preyed upon livestock. Settlers made great efforts to remove them from farming and ranching areas (Herne 1999). The African lion population declined steadily to 500,000 , from an estimated population of one million before colonization, by 1950, 200,000 by 1975 (Myers 1975), and less than 100,000 by the early 1990s (Nowell and Jackson 1996). The most recent population assessment by Riggio (2011) has shown that over 30,000 lions remain in approximately 3 million $\mathrm{km}^{2}$ of sub-Saharan Africa, distributed across a total of 78 lion habitat patches in 27 countries. In his 2002 survey, Chardonnet estimated the lion population in Kenya to be 2749. The latest estimate of Kenya's lion population is a total of 1970 individuals documented by the Kenya Wildlife Service (KWS) with the Maasai land having 825 lions (KWS 2009). Unfortunately, data on population status, trends, and distribution in Kenya before 2002 is lacking, indicating inadequate monitoring of lion population. 
Livestock predation has been a serious challenge to the conservation of threatened predators like lions outside protected areas, with predators potentially adversely affecting the profitability of livestock production and consequently people's livelihoods (Treves and Karanth 2003). These losses greatly affect the economic development of communities living in buffer zones of protected areas like the Olgulului community in the Amboseli region. A combination of factors affects the conservation and survival of lions in the wild. These factors include human population increase and the consequent habitat loss and degradation, reduction in the natural prey base of lions, disease impacts, illegal trade in lion parts, and unsustainable levels of trophy hunting (IUCN Cat Specialist Group 2006a). Most of these factors are linked; for example, livestock predation by lions makes pastoralism unprofitable encouraging pastoralist to turn to crop farming as a source of income. Land cleared and fenced for crop farming leads to habitat loss and degradation and consequently the decline of the natural prey base of lions. Locals also directly hunt lion prey for subsistence or bush meat trade because of widespread poverty caused by a combination of factors including livestock predation. Decline in natural prey indirectly increases human lion conflict as lions turn to livestock as an alternative to wild prey (Valeix et al. 2012). Conflicts caused by livestock predation lead to retaliatory killing of large carnivores (Polisar et al. 2003; Treves and Karanth 2003; Kolowski and Holekamp 2006). Habitat and ecosystem modification by humans is the ultimate cause of wildlife decline (KWS 2009). Therefore, management strategies supporting the conservation of lions should consider the social economic factors like the cost of livestock predation that influence ecosystem modification.

Clearly, the future of lion conservation in the Amboseli ecosystem lies in the hands of the local community within the landscape who are primarily pastoralists. The degree to which communities support and participate in predator conservation will depend on the value that people place on predators (Sillero-Zubiri and Laurenson 2001). This value is likely to be a function of costs (livestock losses or threats to peoples' lives) and benefits (tourism revenue or cultural values) resulting from the presence of predators. There is a general shift in land use from pastoralism to agropastoralism in the Amboseli region that started in the 1980s in a few fertile areas including Kimana group ranch (Okello 2005; Seno and Shaw 2002). The local community in Kimana group ranch ranked agriculture first in terms of importance to subsistence $(65 \%$ agriculture, $50 \%$ pastoralism, $16 \%$ tourism, and $13 \%$ business) (Meguro and Inoue 2011). These changes can be attributed to the relatively high cost of raising livestock resulting from predation. Farming has not spread to OGR because the area receives relatively lower rainfall. A shift to agropas toralism is, however, likely to increase human wildlife conflict in the entire Amboseli ecosystem.
The research questions that this study sought to answer are "Is the cost of livestock predation by lions high enough to cause retaliatory killings?" and "Do other wildlife species cause higher livestock economic loss compared to lions?" Retaliation on carnivores is driven by the proportion of livestock lost, not necessarily the frequency of conflict (Mishra 1997). Lions, like other carnivores, can cause substantial losses to human populations or households living adjacent to protected areas like Amboseli National Park. In retaliation, herders in the Amboseli region "who are mostly Maasai" resort to killing, snaring, and poisoning predators, a situation which has led to mass predator deaths in recent years (Frank et al. 2006).

Before the colonial period, Maasai lived with wildlife and faced similar challenges though to a lesser extent than they experience today. Their livestock competed with wildlife for resources and were hunted and killed by predators. Contrary to the current situation, the Maasai did not kill predators in retaliation (Halderman 1987). Historically, as the government created protected areas in Kenya, the Maasai were gradually denied access and use of resources within the Amboseli National Park (Halderman 1987). The ANP was essentially a national reserve created in 1948 before it was gazetted a national park. This change in status came after national park officials and international wildlife organizations protested, blaming the Maasai for keeping large numbers of "useless cattle" at the expense of wildlife. Kajiando County Council, with little expertise in reserve management, was made responsible by the government for the administration of Amboseli Reserve starting in 1961 (Lindsay 1987). This led to a series of incidents of fraud and mismanagement of the reserve and its revenue. The locals complained of receiving no benefits from the reserve and about the allocation and use of revenue collected from the protected area (Talbot and Olindo 1990). When ANP was gazetted in 1974, the natural water sources for the Maasai and their livestock were locked up in the park. To compensate, the Maasai's alternative water source was constructed 3 years later but they stopped working due to defects soon after their completion (Western 1982a). The locals were not compensated for the loss of grazing land, and even currently, they receive very little or no benefits from the ANP. To show their frustrations and resentments, they killed the most popular wildlife species to both tourist and conservationist including lions, rhinos (Diceros bicornis), and elephants (Talbot and Olindo 1990). Lions could possibly be targeted to date for similar reasons as the problems have not been resolved (personal observation).

The issue of land use conflicts has come to the fore in the country because of a rapidly growing, essentially rural population in the ecologically better endowed highland areas (Campbell et al. 2000). To release this pressure, people have spontaneously moved to the rangelands and established dense settlements thereby destabilizing traditional pastoral 
ecosystems (Campbell et al. 2000). Although the change in pastoral system has indirectly accelerated livestock predation through habitat loss and decline in prey as explained earlier, additional conflict could result from the changing land tenure and land use. The destabilization of local communities by the immigrants may have created resentment among the locals. Lion killing could therefore be a way of communicating their grievances as the lion is the species which attracts the most attention from the stakeholders concerned with both tourism development and wildlife conservation. A study in the Amboseli ecosystem by Okello (2005) showed that the support of free roaming wildlife was dependent on the species that caused livestock predation. The involvement of lions and elephants in human wildlife conflict influenced the support of conservation negatively.

To resolve the existing conflict between the local Maasai and lions in the Amboseli region, more detailed information on the cost and intensity of predation on livestock is key to developing strategies for conserving both large carnivores and wild lands. While most studies have documented the cost of livestock losses to three major predators mainly lion, leopard, and hyena, this study quantified the cost of livestock lost to the lion in comparison to six wildlife species including spotted hyena (Crocuta crocuta), cheetah (Acynonyx jubatus), leopard (Panthera pardus), olive baboon (Papio cynocephalus), black-backed jackal (Canis mesomelas), and African elephant (Loxodonta africana). This was done to reveal the extent of livestock losses to lions in comparison to other species which are less targeted by locals in retaliation. According to Rudnai (1979), the psychological risk or fear of injury or death when communities are living alongside a large dangerous carnivore can motivate the desire to eliminate lions. The lion also acts as a symbol of political conflict over rights to land and wildlife and therefore may be unfairly targeted (Rudnai 1979). The study was conducted in Olgulului group ranch adjacent to Amboseli National Park, and the data collected covered the whole of 2008 up to June 2009.

\section{Methodology}

\section{Study area}

This study was conducted in Olgulului- Ololorashi group ranch located in the southern part of Kenya (Fig. 1) in Kajiando County, which lies between longitudes $36^{\circ} 5^{\prime}$ and $37^{\circ} 5^{\prime}$ east and latitudes $1^{\circ} 0^{\prime}$ and $3^{\circ} 0^{\prime}$ (Wayumba and Mwenda 2006). The ranch is bordered by Eselenkei group ranch to the north, Mbirikani group ranch to the northeast, and former Kimana group ranch to the southeast and the Kenyan-Tanzanian international border to the south. Amboseli National Park is almost completely surrounded by Olgulului-Ololorashi group ranch, thus making it an important wildlife dispersal area for the park. Overall, the ranch covers an area of $1232 \mathrm{~km}^{2}$ and surrounds $90 \%$ of Amboseli National Park (Okello and Kioko 2010). Amboseli National Park which lies contiguous to Olgulului-Ololorashi group ranch covers an area of $392 \mathrm{~km}^{2}$ and forms part of the larger Amboseli ecosystem whose area is approximately $5000 \mathrm{~km}^{2}$ (Ntiati 2002). The group ranch was started in 1975 and had 3418 members

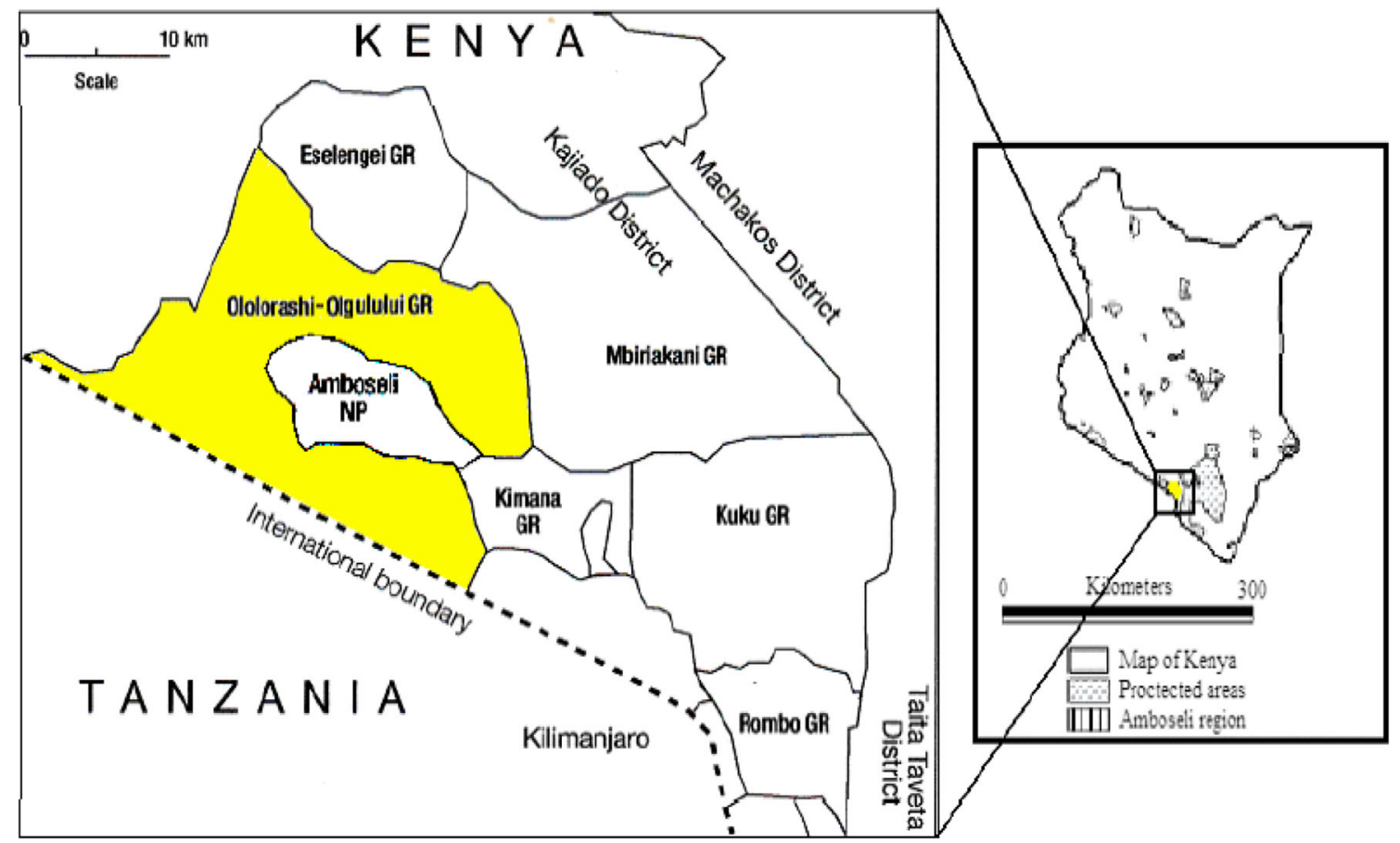

Fig. 1 Map of Amboseli ecosystem showing Amboseli National Park and surrounding group ranches (source: Kenya Wildlife Service, 1996) 
by 2001 . The members increased to 11,500 in 2008 representing $236 \%$ increase in a span of 8 years (Campbell et al. 2003).

The annual rainfall in the Amboseli ecosystem is strongly influenced by mountains, hills, and the rift valley (Norton 1977). High rainfall in the Loitokitok Sub-county occurs around the slopes of Mt. Kilimanjaro and the Chyulu Hills (Norton 1977). Other areas especially the lower rangelands are characterized by lower rainfall; these include the Amboseli basin especially in Mbirikani, Olugulului, and Eselesnkei group ranches (Ntiati 2002). During the wet season, large carnivores including lions and wild herbivores are dispersed throughout much of the Amboseli ecosystem. However, during dry seasons, most of the wildlife especially water-dependent species concentrates in the park, particularly in the swamps whose water is replenished by underground springs originating from melt water on the nearby Mt. Kilimanjaro (Western 1975; Campbell et al. 2003). In the dry season, the Maasai access the park for salt licks and water for their livestock and as such predation of livestock by lions and other carnivores is frequent both inside and outside the park.

OGR receives low rainfall of $500 \mathrm{~mm}$ or less that follows a seasonal pattern of short rains between October and December and long rains between March and May. The rainfall levels make OGR a semiarid to arid land suitable for nomadic pastoralism which has been the traditional land use in the region (Ntiati 2002). The majority of top soils within the Amboseli ecosystem are shallow and unproductive due to recent volcanic activity and therefore unsuitable for agriculture (Katampoi et al. 1990). The recent trends in land use, however, indicate an expansion in rain-fed agriculture in the group ranch and increased permanent settlement (Campbell et al. 2003; Okello and Kioko 2010). The vegetation communities of the Amboseli ecosystem are dominated by bushland, woodland, and open grassland. The most common species include Acacia - commiphora, Acacia tortilis, Acacia xanthophloea, Azima tetracantha, and Suaeda monoica (Githaga et al. 2003).

\section{Methods}

A total of 229 people were interviewed including 199 questionnaire respondents and 30 key respondents drawn from three KWS officials (senior warden, community warden, and ranger), three focus group discussions with five members each, two officials of provincial administration (chief and subchief), two group ranch officials (chairman and treasurer), four village elders, and four verification officers from Amboseli Trust for Elephants and Predator Compensation Fund. The three focus group discussions consisted of elders from different Manyattas, Morans, and young pre-Moran men in each group.

Olgulului group ranch covers a very large area and the Maasai villages are distributed as clusters, and therefore, cluster sampling method was used to select villages included in the study to ensure the community views were well represented (Zar 1999). The western side of the GR consisted of 26 villages (a village may contain more than one manyatta depending on the settlement density of a particular area) in total from which 11 villages with a population of approximately 2000 were selected using cluster sampling. The household was used as the sampling unit, since manyattas often consist of more than one household. Using systematic sampling, every tenth household in each village was visited until a total of 199 respondents were interviewed.

Three people from the group ranch were recruited as research assistants to administer the household questionnaire among the residents of Olgulului group ranch. With assistance of the research assistants, 199 respondents were interviewed within a period of 4 weeks in June 2009. Since the interviews were done during the day, the researcher and her team had an opportunity to interview a few women and elderly men as they had been left in the bomas when young morans went out to herd livestock. The research team was able to interview morans at grazing sites as the assistants knew which boma each moran belonged to. The questionnaire survey was done using a semistructured questionnaire, which included both closed and open-ended questions. The semistructured questionnaire allowed for a much wider range in statistical comparisons, and also allowed interviewees to add their own personal experiences and elucidate subject matters that may have been too restricted in highly structured questionnaire format (Hazzah 2006). The questionnaire was divided into four sections. The first section focused on demographic information (gender, age, level of education, employment, and livelihood strategy). The second section dealt with various aspects of land use and livestock production, including the type and number of livestock kept per household. The section also dealt with other economic activities such as agropastroralism and crop farming. Questions on losses of livestock to wildlife including when and where attacks on livestock occurred and livestock lost to other causes of death were covered in the third section. The final section of the questionnaire dealt with interventions aimed at reducing livestock losses due to wildlife.

In addition to the household surveys, three focus group discussions with five members each were held with members of the community consisting of young pre-moran and morans who were livestock herders and elderly men from different villages. The discussions were done with the aid of the three trained research assistants using semistructured interview sessions, and new questions were adopted as the discussions progressed. Efforts to hold similar discussions with women were fruitless as getting women in a group was hard because they were busy doing household chores and taking care of children. Men were easily found in groups drinking beer or at slaughter sites where they were interviewed on the history of livestock predation, the major causes of livestock deaths, the species that attacked 
Fig. 2 Livestock killed by different wildlife species in percentage

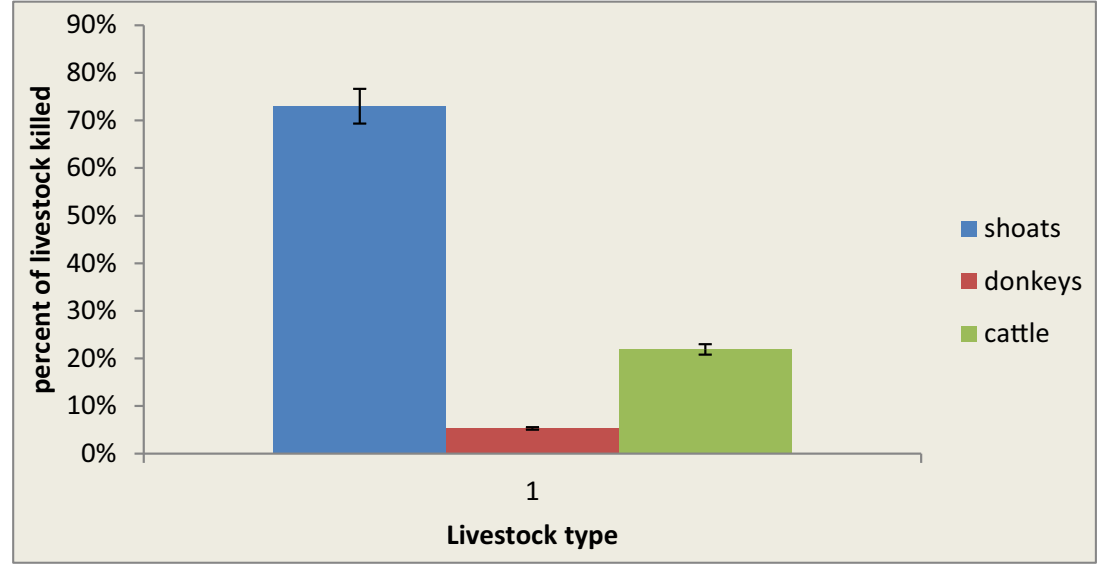

livestock most frequently, attitudes to livestock predation by lions and potential solutions, benefits received from wildlife conservation, and views about the predator compensation fund in the group ranch.

Key informers were interviewed using semistructured questionnaires to gather information not captured in other surveys described above. Among the key informants were Kenya Wildlife Service officers, local leaders, group ranch officials, Amboseli Trust for Elephants and Predator Compensation Fund officials. Issues discussed during the interviews included the role of the KWS in reducing human wildlife conflict, collaboration between compensation organizations and KWS, administration of compensation schemes, whether depredation had increased in recent years, and how benefits from wildlife conservation were shared among group ranch members. Key informants also provided insights on sensitive information like the methods used in killing offending wildlife by the locals.

There are some potential disadvantages of relying solely on questionnaires that might have influenced livestock loss data. Firstly, as Rasmussen (1999) has documented, livestock holders may wrongly attribute stock that has died of natural causes to predation. This may happen through sheer neglect or prejudices towards specific carnivore species. Secondly, livestock keepers might also have had an interest in overestimating the rate of loss, expecting compensation in return. This may have been influenced by the presence of a predator compensation scheme that began operating in OGR in the year 2008 .

To avoid this misconception, respondents were informed that the research was purely academic and that no benefits were to be expected. Respondents often bias their recollection of past events in favor of larger species, especially when sampling from multiple years (Kruuk 1980). This was reduced by collecting data for 2008 up to June 2009, instead of using a longer time period. Despite these limitations, several studies show that the livestock keeper's perception of livestock depredation gives a relatively reliable index of livestock predation (Kruuk 1980; Woodroffe et al. 2005b).
Data from the questionnaires was analyzed using the Statistical Package for Social Scientists (SPSS) version 12.0 (SPSS Inc., Chicago, USA) computer software. ANOVA (Zar 1999) was used to test the statistical difference in means of variables inclusive of the total number of livestock lost to various wildlife species and economic costs associated with the losses of livestock to different wildlife species. The level of significance used for all statistical tests is 0.05 . The information collected from focus group discussions and key informant interviews was used to validate and supplement the perceptions of the household respondents.

Average prices of different livestock types (cattle US\$332.33, shoats (sheep and goats) US\$77.73, and donkeys US\$58.36) were computed using different market prices that livestock were sold at as given by respondents and used to calculate the cost of livestock lost to various wildlife species. Values of economic losses are discussed in US\$, using the exchange rate of $1 \mathrm{US} \$=78 \mathrm{Kshs}$ at that time.

\section{Results}

\section{Livestock lost to lions and other wildlife species}

The 199 respondents interviewed reared a total of 51,789 livestock with an average of $260(\mathrm{SE}= \pm 18.45)$ heads of livestock per household. The shoat population was the highest representing $63.2 \%(n=32,719)$ of the total livestock kept followed by the cattle population $(34 \%, n=17,601)$ while the donkey population was the least $(2.8 \%, n=1469)$. Pastoralism was practiced by $98.2 \%$ of the respondents. Agro-pastrolism (mixture of rearing livestock and crop farming) was practiced by $46.9 \%$ of the population while $32.9 \%$ practiced only livestock keeping. Those who practice farming hire land outside OGR in group ranches where land subdivision has been done. A total of 7234 livestock of the respondents interviewed were lost to wildlife within 18 months 
Fig. 3 Percent of livestock killed by each wildlife species

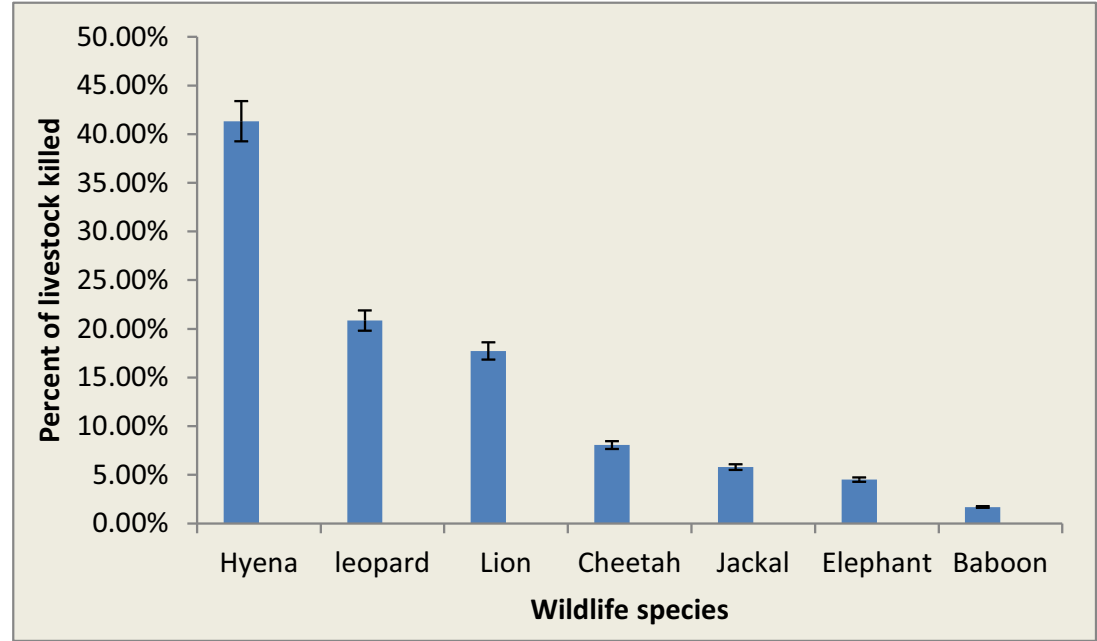

between 2008 and June 2009. Each household lost an average of 36.35 ( $\mathrm{SE} \pm 2.8$ ) livestock within the period covered by the study. The highest number of kills was reported for shoats representing $73 \%$ ( $n=5280)$ of the total livestock killed by wildlife, which was three times more than that of cattle killed by wildlife $(21.9 \%, n=1587)$ and almost 20 -fold greater than the total number of donkeys lost to wildlife $(5.3 \%, n=367)$ (Fig. 2). There was a significant variation in the mean number of livestock types lost to wildlife $(F=288.016, \mathrm{df}=2,4158$, $p<0.001)$. On average, each household lost $26.6(\mathrm{SE}= \pm 2.1)$ shoats, $7.8(\mathrm{SE}= \pm 0.89)$ cattle, and $1.64(\mathrm{SE}= \pm 0.24)$ donkeys within 18 months.

Seven wildlife species (Fig. 3) were reported to kill livestock reared by the respondents. Hyenas killed $41.3 \%$ ( $n=2989)$ of the total livestock lost to different wildlife species while attacks by lions claimed $17.7 \%(n=1282)$. Hyenas claimed $5.8 \%$ of the total livestock reared by farmers while lions killed $2.5 \%$ of the total livestock population. The overall percentages of total livestock lost to other wildlife species were as follows: leopard $(20.9 \%, n=1508)$, cheetah $(8 \%$, $n=585)$, jackal $(5.8 \%, n=421)$, elephant $(4.5 \%, n=326)$, and baboon $(1.7 \%, n=123)$ (Fig. 3). There was a significant variation in the mean number of livestock killed by the various wildlife species $(F=101.053, \mathrm{df}=6,4158, p<0.00)$.

Table 1 Tukey test comparisons for numbers of livestock killed by major predators

\begin{tabular}{lllr}
\hline$(I)$ predator & $(J)$ predator & Mean difference $(I-J)$ & \multicolumn{1}{c}{$p$} \\
\hline Lion & Leopard & -0.0353 & 0.830 \\
& Hyena & $-0.4560^{*}$ & $<0.001$ \\
Leopard & Lion & 0.0353 & 0.830 \\
& Hyena & $-0.4206^{*}$ & $<0.001$ \\
\multirow{2}{*}{ Hyena } & Lion & $0.4560^{*}$ & $<0.001$ \\
& Leopard & $0.4206^{*}$ & $<0.001$ \\
\hline
\end{tabular}

* The mean difference is significant at the 0.05 level
Wildlife killed $14 \%(n=7234)$ of the total $(n=51,789)$ livestock kept by the respondents over a period of 18 months. The three major predators of livestock which included hyenas, leopards, and lions killed $5.6 \%$ $(n=2989), 2.9 \%(n=1508)$, and $2.5 \%(n=1282)$ of the total livestock owned by the respondents, respectively. These three major predators claimed $11.2 \%$ of all livestock $(n=51,789)$ kept by the respondents, and there was a significant difference in the mean number of livestock killed by leopards, lions, and hyenas $(f=34.9, \mathrm{df}=2$, 1782, $p<0.001)$. After carrying out a Tukey test, the numbers of livestock predated on by lions and hyenas were found to be significantly different $(q=7.52$, $p<0.00$ ), while those predated on by lions and leopards were not significantly different $(q=0.58, p=0.83)$ (Table 1).

Most of the attacks by various wildlife species were directed at shoats. Hyenas and leopards attacked shoats more frequently claiming the lives of 47 and $28 \%$ of all the shoats lost to wildlife, respectively. Lions killed the lowest number of shoats $(1.6 \%)$, but killed more cattle $(71.8 \%)$, which was more than six times those killed by hyenas (13.8\%) (Fig. 4). On average, lions killed 5.72 $(\mathrm{SE}= \pm 0.6)$ while hyenas killed an average of 1.1 $(\mathrm{SE}= \pm 0.33)$ cattle per household.

\section{Economic cost of livestock lost to lions and other wildlife species}

The total economic cost attributed to livestock losses amounted to US\$959,240.20 with cattle accounting for $55 \%$ (US\$529,069.40), shoats $42.67 \%$ (US\$410,414.40), and donkeys $2.3 \%$ (US\$22,176.80) (Fig. 5). On average, each household lost US\$4820.3 (SE $= \pm 424$ ) to wildlife within the period of 18 months covered by the survey and US\$1952.44 ( $\mathrm{SE}= \pm 206)$ to lions alone. With reference to individual wildlife species, lions accounted for $40.5 \%$ 
Fig. 4 Percentage of livestock types killed by different wildlife species

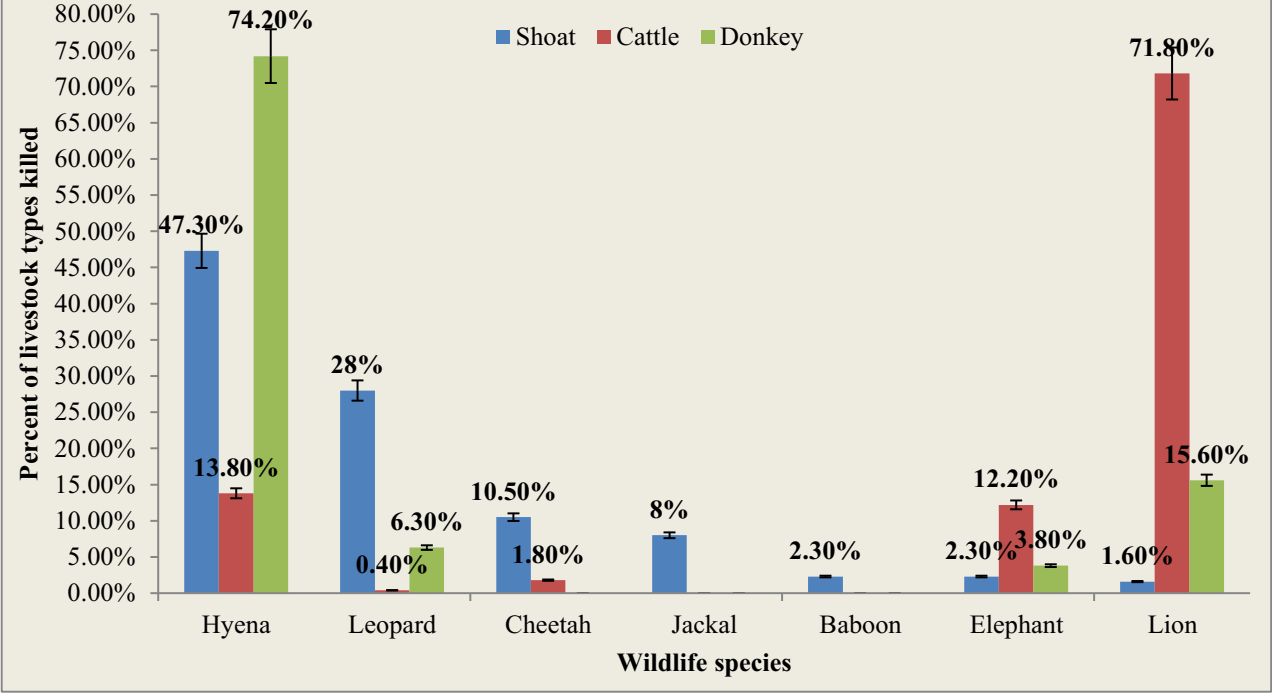

(US\$388,535.2) of total economic losses followed by hyenas $29.5 \%$ (US\$282,843.1), leopards $12.4 \%$ (US\$118,553.5), elephants 7.7\% (US\$74,206.6), cheetahs $5.5 \%$ (US\$52,816.71), jackals 3.4\% (US\$32,724.33), and baboons $1 \%$ (US\$9560.79), respectively (Fig. 6). The differences between the mean costs incurred due to losses attributed to lions, hyenas, and leopards were significant $(F=34.297$, df $=2,1782, p<0.001)$. The costs of livestock lost to hyenas and lions were not significantly different ( $q=0.24, p=0.968)$ (Table 2).

\section{Discussion}

In the study area, wildlife claimed among the highest percentage of livestock reported in Africa (14\%) costing pastoralists US\$959,240.20 within a period of 18 months. Annual losses of $2.4 \%$ for all livestock were reported in ranches in southeastern Kenya by Patterson et al. (2004), and Butler (2000) reported 5\% losses in Zimbabwe's Gokwe community lands. Graham et al. (2005) reported worldwide losses to predation ranging from 0.02 to $2.6 \%$ of livestock per year. In Northern Kenya, similarly high losses have been reported where attacks on livestock by wild dogs (Lycaon pictus) cost the local community about KSh 2.2 million (US\$2870) during a period of 3 months in 2003 (Woodroffe and Lindsey 2004). In 1999, sheep and lamb losses from predation in the USA resulted in a direct loss of $\$ 16.5$ million (Jones 2004).

Lions predated on $2.5 \%$ of the total livestock kept by pastrolists. These results are at par with many African studies. For instance, in the neighboring Mbirikani group ranch, lions killed $0.1 \%$ of the total livestock herd while commercial ranches adjoining Tsavo lost $2.2 \%$ of cattle to lions annually (Patterson et al. 2004). Although hyenas and leopards killed far more livestock compared to lions, the cost of livestock lost to lions was higher because lions killed more cattle which
Fig. 5 Total economic losses of different livestock types

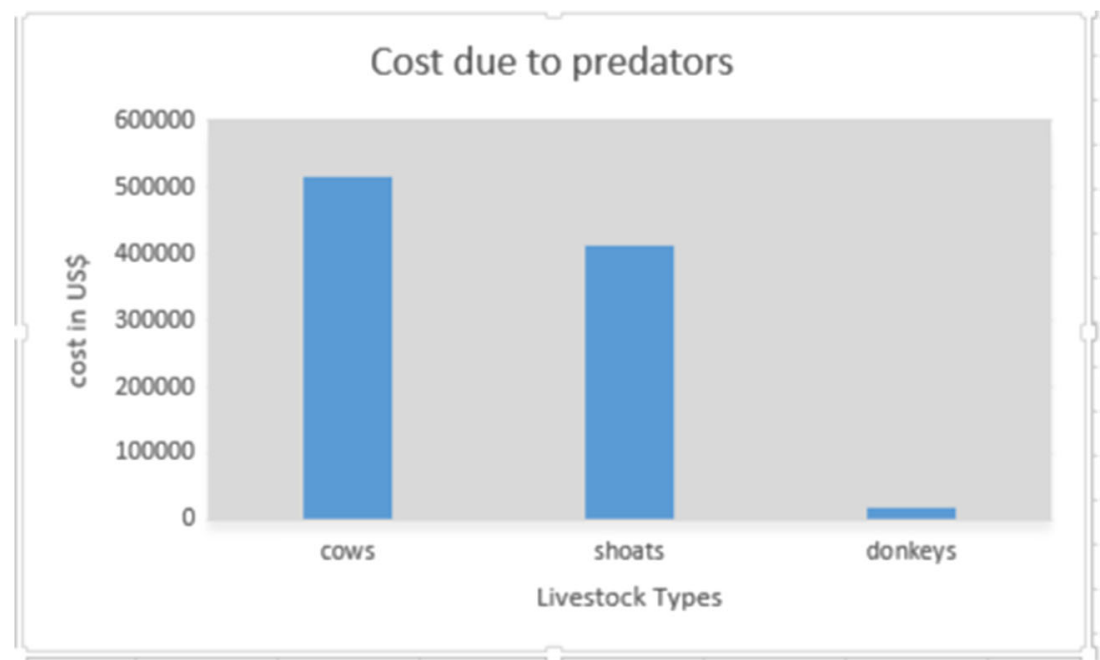


Fig. 6 Economic loss to each wildlife species in percentage

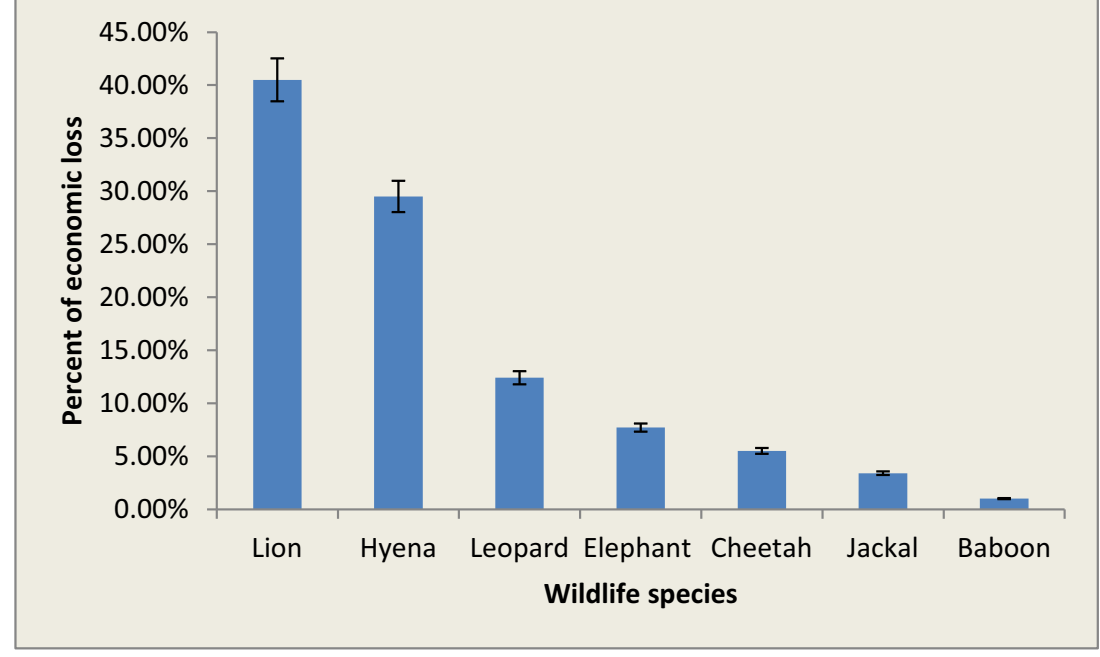

have higher economic and cultural value. In Waza National Park, slightly fewer cattle than shoats were lost to lion predation in 2002 (335 cows, 373 shoats) but the economic impact of cattle predation which stood at US $\$ 797$ per livestock owner per year was almost eight times higher (Van Bommel and De Iongh 2007).

In comparison to other studies, lions accounted for the lowest percentage of total livestock kills by large predators in the study area. For instance, lions accounted for 93\%, leopards $3 \%$, hyenas $2 \%$, and cheetahs $2 \%$ of livestock attacks near Voi, Kenya (Kerbis and Gnoske 2002). Patterson et al. (2004) noted that lions were responsible for $86 \%$ of all livestock kills in commercial ranches in southeastern Kenya. In Taita and Rukinga Ranches of Kenya, lions accounted for 83.5-95.7\% of livestock predated annually; the spotted hyena was responsible for $0-9.1 \%$, cheetah $0-4.9 \%$, and elephants $0-3.6 \%$ of the attacks (Patterson et al. 2004). While Ogada et al. (2003) has documented that lions accounted for about $63 \%$ of livestock kills in commercial ranches in Northern Kenya. Karani (1994) in a study of group ranches surrounding Maasai Mara National Reserve reports that lions were responsible for $19 \%$ of livestock killed by different predators. Current study results revealed that lions were responsible for

Table 2 Tukey test and multiple comparisons for cost of livestock lost to major predators

\begin{tabular}{lllr}
\hline$(I)$ predator & $(J)$ predator & Mean difference $(I-J)$ & \multicolumn{1}{c}{$p$} \\
\hline Lion & Leopard & $5.6757^{*}$ & $<0.001$ \\
& Hyena & -0.1945 & 0.968 \\
\multirow{2}{*}{ Leopard } & Lion & $-5.6757^{*}$ & $<0.001$ \\
& Hyena & $-5.8702^{*}$ & $<0.001$ \\
\multirow{2}{*}{ Hyena } & Lion & 0.1945 & 0.968 \\
& Leopard & $5.8702^{*}$ & $<0.001$ \\
\hline
\end{tabular}

* The mean difference is significant at the 0.05 level
$17.7 \%$ of all livestock killed, a fact that concurs with the results of Karani (1994). In the neighboring Mbirikani group ranch, lions were blamed for $7 \%$ of predation cases in 2006 (Maclennan et al. 2009).

The differences between the results of the present study and those of other regions cited above could be attributed to densities of different carnivores in different regions. In a study carried out in ANP and the surrounding group ranches by Okello between 1999 and 2002, it was reported that lions and spotted hyenas had densities of $0.03 \mathrm{lion} / \mathrm{km}^{2}$ and 0.93 hyena $/ \mathrm{km}^{2}$, respectively. In the present study, high depredations by hyenas could be due to high densities of hyenas in the Amboseli ecosystem. On the other hand, the low lion densities in the study area explain their lower depredation levels although they can become a major cause of conflict if their densities increase without strict measures of reducing depredation rates being put in place. Some researchers have documented increases in livestock depredation rates with increases in carnivore density (Stahl and Migot 2001; Stoddart et al. 2001). A significant increase in killing and poisoning of lions has been reported in Mbirikani group ranch and adjacent group ranches in Amboseli ecosystem since 2001. These killings have no doubt reduced lion numbers in the study area implying reduced numbers of killings of livestock particularly cattle. This observation explains to some extent the deviation in the findings of Maclennan et al (2009), Patterson et al. (2004), and Ogada et al. (2003) with those of the present study. Evidence from these study results and others reviewed suggests the spotted hyenas, leopards, and lions are the major predators of livestock.

Although there was no significant difference between the cost of livestock killed by both lions and hyenas $(q=0.24$, $p=0.968)$, lions are more vulnerable to retaliatory killing since lions normally defend a livestock carcass against humans, thus exposing them to frequent confrontation while hyenas shy away from people and leopards are good at hiding 
(Kissui 2008). In addition, lions kill cattle more frequently which are of more monetary and cultural values to pastoralists than sheep and goats. The economic value of one cattle is equivalent to about four goats or sheep. Most critically, lions mostly attack livestock during the day when people are armed to protect their livestock leading to direct confrontations whereas leopards and hyenas mostly attack livestock at night, hence avoiding to a big extent confrontation (Packer and Kissui 2007).

Other wildlife species which attacked and killed livestock within the study area were cheetahs $(8.1 \%)$, jackals (5.8), elephants $(4.5 \%)$, and baboons $(1.7 \%)$. Findings revealed that the local people incur losses from elephants which not only kill their livestock but also destroy enclosures, making livestock more vulnerable to predators. Officials from Amboseli Trust for Elephants stated the elephants killed both livestock and humans upon provocation. Due to their good memory, they always remember any place they have been provoked before, and portray a violent behavior upon visiting the area later. They further alluded that there are specific elephant families which are known to attack livestock, particularly female elephants with young ones whereas bull elephants rarely attack livestock. Results from focus group discussions with local people further revealed the hyenas are mostly opportunistic feeders and feed on livestock already killed by elephants if they notice the carcass before the herders do. Although results showed hyenas predated on more livestock, their number of attacks and kills could be lower if the foregoing factors about elephants and opportunistic feeders are considered. Other wildlife species like the jackal and the baboon normally attack the young of goats (kids) and sheep (lambs). Baboons mostly attack lambs near bomas where they normally scavenge on waste food materials. The economic losses and costs incurred from jackals and baboons are, however, low compared to those incurred from lions, elephants, and other species like leopards.

\section{Conclusion and recommendations}

Economic losses caused by lions in the study area are among the highest reported in East Africa and in comparison to other wildlife species. These losses are magnified by the fact that livestock keeping is the primary source of livelihood in the study area. Livestock rearing contributes to $85 \%$ of the total household income for those who practice pastoralism only (KFSSG 2010). Therefore, the belief that carnivore conservation, particularly the lion, is a non-affordable luxury is widespread among the local community in the study area because of the opportunity cost in the form of lost livestock. Most of the local people believe that a choice has to be made between economic development and lion conservation. The most important direct impact of these losses is retaliatory killing of lions. An average of 12.5 lions were killed per year between 2003 and 2008 by residents of OGR (Hazzah et al. 2014). In 2010 , barely a year after this study, a total of 16 lions were killed by members of the OGR in a span of 6 months (Hazzah et al. 2014). The major indirect impact of the high cost of livestock predation by lions might include changes in land use, with more people turning to crop farming in future. Effective conservation of lions can only be achieved if the impact of wildlife on livelihoods can be reduced to a level that local people will tolerate.

Direct compensation for livestock killed by wildlife in most areas is given to affected pastoralists to offset the economic losses incurred (Maclennan et al. 2009). This provides direct incentive for pastoralists to forego retaliatory killing of lions after cases of predation. Although the Amboseli Predator Compensation Fund and Amboseli Trust for Elephants compensate pastoralists in the study area for livestock killed by predators and elephant, respectively, the two funds pay only a fraction of the real value of the livestock lost which creates a negative opinion towards wildlife. Additionally, the process of verifying claims may cause delay in payments of lost livestock bringing more resentment towards wildlife conservation. The compensation funds are also not very sustainable as they rely heavily on donors for funding, yet they can pull out any time. This strategy is also not sustainable since it does not encourage villagers to protect their livestock from wildlife attacks. In the neighboring Mbirikani group ranch, penalties put in place for poor herding by the Mbrikani Predator Compensation Fund did not reduce negligent herding from 2004 to 2006 (Maclennan et al. 2009). In the study area, pastoralists were said to neglect weak livestock to be predated on so that they could be compensated.

Financial sustainability of any direct incentive scheme is a priority (Nyhus et al. 2005), more so if the motivation to conserve wildlife becomes purely financial, since withdrawal of the financial incentives can be detrimental to long-term conservation (Gadd 2005). In the OGR, the Predator Compensation Fund was initiated in 2008 to increase local tolerance to livestock predation (Lions Guardians Annual Report 2009). The Wildlife Conservation and Management Act 2013 also provides for the formation of a compensation scheme for financing compensation claims like livestock predation. As mentioned earlier, most of these programs fail due to lack of funds and locals are left even more bitter resulting in more and intensified persecution of wildlife. This study can therefore be used as a model to assess the economic cost of livestock predation per year which can in turn be used to determine the cost of compensation in the long term.

An alternative strategy to compensation would be an insurance scheme where livestock insurance offered to pastoralists covers livestock from the risk of wildlife attack, and involves the local community and local governing bodies paying a premium share of the insurance, thus allowing rural 
inhabitants to make a minimum annual cost to be refunded in the event of livestock losses (Madhusudan 2003). All stakeholders, including the local community who suffer the cost of living with lions, private investors who benefit from the presence of lions, KWS, and others, should be involved in funding and management of such insurance. These insurance programs can encourage good livestock husbandry by giving cash rewards to livestock owners with low predation cases. This could be replicated locally as it happens in the Spiti valley in India where a livestock insurance program provides cash rewards to farmers who have the fewest livestock predation cases (Mishra 2003). Another alternative to compensation would be to pay communities for the number of living lions instead of dead livestock. This would greatly avoid the pitfalls of compensation mentioned earlier and the secret killing of lions (Frank 2010).

Since lions are often subjected to retaliatory killing when they venture into communal lands, planning of the region should consider other economic activities such as farming alongside wildlife conservation since these activities contribute indirectly to livestock depredation. Besides this, information on the spatial temporal movements of lions and other wildlife would identify important wildlife refuge areas, and also help incorporate such information into village land use plans that would help pastoralists to avoid herding their livestock in areas frequently used by lions.

Acknowledgements First and foremost, I thank the Almighty God for the gift of life and for giving me good health throughout the study period. I am grateful to a number of people whose efforts I appreciate for making this work a success. Foremost, I wish to acknowledge my co-authors, Professor Hellen Ipara and Dr. John Kiringe, for their support, advice, and constructive criticism during proposal writing, the collection and processing of data, and the writing of the manuscript. Secondly, I thank my husband Grey Mausi and other family members, for tolerating my long absence during data collection and giving me moral support as I wrote this manuscript. Lastly, I sincerely thank Professor Geoffrey Wahungu for organizing funding for the research from the University of Leiden in the Netherlands, without which the study could not have been possible.

Open Access This article is distributed under the terms of the Creative Commons Attribution 4.0 International License (http:// creativecommons.org/licenses/by/4.0/), which permits unrestricted use, distribution, and reproduction in any medium, provided you give appropriate credit to the original author(s) and the source, provide a link to the Creative Commons license, and indicate if changes were made.

\section{References}

Butler JR (2000) The economic costs of wildlife predation on livestock in Gokwe communal land, Zimbabwe. Afr J Ecol 38:23-30

Campbell D, Gichohi H, Mwangi A, Chege L (2000) Land use conflict in Kajiado District, Kenya. Land Use Pol 17:337-348

Campbell DJ, Lusch DP, Smucker T, Wangui EE (2003) Root causes of land use change in the Loitokitok area, Kajiado District, Kenya. In
LUCIDWorkingPaper: East Lansing, Michgan, Nairobi, Kenya: LUCID, Michigan State University, ILRI, UNEP/GEF. 37p

Chardonnet, Ph. (ed.) (2002) Conservation of the African lion: contribution to a status survey. International Foundation for the Conservation of Wildlife, France and Conservation Force, USA

Frank LG (2010) Living with lions: lessons from Laikipia. Conserving wildlife in African landscapes: Kenya's Ewaso Ecosystem. Smithsonian Institution Scholarly Press

Frank LG, Maclennan S, Hazzah L, Bonham R, Hill T (2006) Lion killing in the Amboseli-Tsavo Ecosystem, 2001-2006, and its implications for Kenya's lion population

Gadd ME (2005) Conservation outside of parks: attitudes of local people in Laikipia, Kenya. Environ Conserv 32:50-63

Githaga JM, Reid R, Muchiru AN, Van Dijk S (2003) Survey of water quality changes with land use type in the Loitokitok area, Kajiado District, Kenya. In: The Land Use Change, Impacts and Dynamics Project Working Paper 35. International Livestock Research Institute, Nairobi

Graham K, Beckerman AP, Thirgood S (2005) Human-predator-prey conflicts: ecological correlates, prey losses and pattern of management. Biol Conserv 122:159-171

Halderman J (1987) Development and famine-risk in Kenya Maasail and political science. University of California-Berkeley, Berkeley, p 544

Hazzah LN (2006) Living among lions (Panthera leo): coexistence or killing? Community attitudes towards conservation initiatives and the motivations behind lion killing in Kenyan Maasai land. MSc. Thesis, University of Wisconsin

Hazzah L, Dolrenry S, Naughton L, Edwards CTT, Mwebi O, Kearney F, Frank L (2014) Efficacy of two lion conservation programs in Maasailand, Kenya. Conserv Biol 28(3):851-860

Herne B (1999) White hunters. Henry Holt and Co., New York, pp 78-86

IUCN (2006a) Regional conservation strategy for the lion Panthera leo in eastern and southern Africa. IUCN SSC Cat Specialist Group, Yaounde

Karani IW (1994) An assessment of depredation by lions and other predators in the group ranches adjacent to Maasai Mara National Reserve. Moi University, p 70

Katampoi K, Genga G, Mwangi M et al (1990) Kajiado district atlas. ASAL Program, Kajiado

Kenya Food Security Steering Group (KFSSG) (2010) The 2010 short rains season assessment report

Kerbis JC, Gnoske TP (2002) The science of man-eating among lions (Panthera leo) with a reconstruction of the natural history of the man-eaters of Tsavo. Journalof East African Natural History 90:1-40

Kissui BM (2008) Livestock predation by lions, leopards, spotted hyenas, and their vulnerability to retaliatory killing in the Maasai steppe. Animal Conservation, Tanzania, pp 1-11

Kolowski JM, Holekamp KE (2006) Spatial, temporal, and physical characteristics of livestock depredations by large carnivores along a Kenyan reserve border. Biol Conserv 128:529-541

Kruuk H (1980) The effect of large carnivores on livestock and animal husbandry in Marsabit District. IPAL Technical, Kenya

KWS (2009) National conservation and management strategy for lion and spotted hyena in Kenya (2009-2014). Kenya Wildlife Service, Nairobi

Lindsay WK (1987) Integrating parks and pastoralists: some lessons from Amboseli. In: Anderson D, Grove R (eds) Conservation in Africa: people, policies, and practice. Cambridge University Press, Cambridge, pp 149-167

Maclennan SD, Groom RJ, Macdonald DW, Frank LG (2009) Evaluation of Compensation Scheme to Bring about Pastoralist Tolerance of Lions. Biol Conserv

Madhusudan MD (2003) Living amidst large wildlife: livestock and crop depredation by large mammals in the interior villages of Bhadra Tiger Reserve, South India. Environ Manag 4(31):466-475 
Meguro T, Inoue M (2011) Conservation goals betrayed by the uses of wildlife benefits in community-based conservation: the case of Kimana Sanctuary in Southern Kenya. Human Dimensions of Wildlife: an International Journal 16(1):30-44

Mishra C (1997) Livestock depredation by large carnivores in the Indian trans Himalaya: conflict perceptions and conservation prospects. Environ Conserv 24:338-343

Mishra J (2003) People and the environment: approaches for linking household and community surveys to remote sensing and GIS. Kluwer Academic Publishing, Boston, pp 173-199

Myers N (1975) The silent savannahs. Int Wildl 5:5-10

Norton G (1977) Aspects of climate in Kajiado District. UNDP/FAO Kenya Wildlife Management Project, Project Working Document 13, Nairobi

Nowell K, Jackson P (1996) Wild cats: status survey and conservation action plan. IUCN/SSC Cat Specialist Group, Gland

Ntiati P (2002) Group ranches subdivision study in Loitokitok Division of Kajiado District, Kenya. In: The Land Use Change Impacts and Dynamics Project Working Paper 7. International Livestock Research Institute, Nairobi

Nyhus PJ, Osofsky SA, Ferraro P, Madden F, Fischer H (2005) Bearing the costs of human-wildlife conflict: the challenges of compensation schemes. In: Woodroffe R, Thirgood S, Rabinowitz A (eds) People and wildlife: conflict or co-existence? Cambridge University Press, Cambridge, pp 107-121

Ogada MO, Woodroffe R, Oguge N, Frank L (2003) Limiting depredation by African carnivores: the role of livestock husbandry. Conserv Biol 6(17):1521-1530

Okello M (2005) Land use changes and human-wildlife conflicts in the Amboseli area, Kenya. Hum Dimens Wildl 10:19-28

Okello M, Kioko J (2010) Contraction of wildlife dispersal area in Olgulului-Ololorashi group ranch around Amboseli national park, Kenya. The Open Conservation Biology Journal 4:28-39

Packer C and Kissui BM (2007) Managing human-lion conflict. Transactions of the $72^{\text {nd }}$ North American Wildlife and Natural Resources Conference E.4 March 20 to 24, 2007 in Portland, Oregon

Patterson BD, Kasiki SM, Selempo E, Kays RW (2004) Livestock predation by lions (Panthera leo) and other carnivores on ranches neighboring Tsavo National Park, Kenya. Biol Conserv 119:507-516

Polisar J, Maxit I, Scognamillo D, Farrell L, Sunquist ME, Einsenberg JF (2003) Jaguars, pumas, their prey base and cattle ranching: ecological interpretation of management problem. Biol Conserv 109:297-310

Rasmussen GS (1999) Livestock predation by the painted hunting dog Lycaon pictus in a cattle ranching region of Zimbabwe: a case study. Biol Conserv 88:133-139
Riggio JS (2011) The African lion (Panthera leo leo): a continent-wide species distribution study and population analysis. Nicholas School of the Environment of Duke University

Rudnai J (1979) Ecology of lions in Nairobi National Park and the adjoining Kitengela Conservation Unit in Kenya. African Journal Ecology 17:85-95

Seno SK, Shaw WW (2002) Land tenure policies, Maasai traditions, and wildlife conservation in Kenya. Soc Nat Resour 15:79-88

Sillero-Zubiri C, Laurenson MK (2001) Interactions between carnivores and local communities: conflict or co-existence? In: Gittleman JL, Funk SM, Macdonald DW, Wayne RK (eds) Carnivore conservation. Cambridge University Press, Cambridge, pp 282-312

Stahl LP, Migot P (2001) The effect of removing lynx in reducing attacks of sheep in the French Jura mountains. Biol Conserv 101:15-22

Stoddart LC, Griffiths RE, Knowlton FF (2001) Coyote responses to changing jackrabbit abundance affect sheep predation. J Range Manag 54:15-20

Talbot L, P. Olindo (1990) Kenya, the Maasai Mara and Amboseli Reserves. In: Kiss, A. (ed.) Living with wildlife - wildlife resource management with local participation in Africa, World Bank Technical Paper 130, pp. 67-74

Treves A, Karanth KU (2003) Human-carnivore conflict and perspectives on carnivore management worldwide. Conserv Biol 17:1491-1499

Valeix M, Hemson G, Loveridge AJ, Mills G, Macdonald DW (2012) Behavioral adjustment of a large carnivore to access secondary prey in a human dominated landscape. J Appl Ecol 49:73-81. doi:10. $1111 / j .1365-2664.2011 .02099 . x$

Van Bommel L, De Iongh HH (2007) Factors affecting livestock predation by lions in Cameroon. Afr J Ecol 45:490-498

Wayumba N and Mwenda N (2006) The impact of changing land tenure and land use on wildlife migration within group ranches in Kenya: a case study of the Amboseli Ecosystem, 5th FIG Regional Conference

Western D (1975) Water availability and its influence on the structure and dynamics of a savanna large mammal community. East Africa Wildlife Journal 13:265-286

Western D (1982a) Amboseli National Park: enlisting landowners to conserve migratory wildlife. Ambio 11(5):302-308

Wildlife Conservation and Management Act 2013

Woodroffe R, Lindsey MK (2004) Livestock predation by endangered African wild dogs (Lycaon pictus) in Northern Kenya. Biol Consery 124:225-223

Woodroffe R, Lindsey P, Romanach S, Stein A, ole Ranah SMK (2005b) Livestock predation by endangered African wild dogs (Lycaon pictus) in northern Kenya. Biol Conserv 125:225-234

ZAR JH (1999) Biostatistical analysis, 4th edn. Prentice-Hall, Upper Saddle River, New Jersey 